Brit. J. vener. Dis. (1966), 42, 276.

\title{
NEW METHODS OF CONTACT TRACING IN INFECTIOUS VENEREAL DISEASES* ${ }^{*}$ \\ BY
}

\author{
A. M. LAMB \\ Department of Venereal Diseases, The London Hospital
}

During 1965 more active methods of contact tracing in cases of infectious venereal diseases were under trial at the Whitechapel Clinic. The intention was that I should try to gain enough information from the male patients who were suffering from syphilis and gonorrhoea to ensure the attendance of their contacts and thereby reduce the spread of venereal infection.

The following procedure was adopted. After a male patient was found to have been infected he was asked to see me before leaving the clinic. The majority of patients were co-operative and tried to be helpful. When possible, I completed a form giving details of the contact, including if possible the name and address, full description, and any other relevant information. I tried to build up a composite picture of the woman: of her habits, such as smoking, drinking, drug-taking, etc., and of the cafés and public houses she might frequent. This interview could be long and although it demanded patience and perseverance, it was sometimes most rewarding and I rarely met with rudeness or antagonism. I always tried to secure the patient's help in the tracing of a contact. If an infected man knew the girl who was the source of his infection, he was a more appropriate person to find and approach her than an outsider. Nevertheless, I always suggested that I should be willing to visit if he so preferred. This suggestion had the effect of either confirming the patient in his determination not to speak to the girl himself or of persuading him to undertake the task to avoid the embarrassment which might result from an outsider making the approach. In many ways I prefer to make the visit myself because speed is an important factor and promises from patients are not always fulfilled; much depended upon the relationship between the man and his contact.

Many patients asked their contacts to telephone me to discuss the problem, thus providing them with a personal link with someone and smoothing the way to a first visit. This I found a good idea as I could suggest that they came to talk to me at the clinic and could then fairly easily inveigle them into a consulting room. One young girl, who seemed genuinely

\footnotetext{
* Received for publication May 12, 1966.

$\dagger$ An address given to the Medical Society for the Study of Venereal eases.
}

terrified of being examined, arrived by this method. I was very anxious that she should be seen by the doctor because she was the contact of a young man who had primary syphilis. I persuaded her to come and talk with me and managed to get her to see a doctor and to submit to tests. It took a great deal of time and effort to allay her fears but this was well worthwhile for she was found to be suffering from both secondary syphilis and gonorrhoea. She was, moreover, a very promiscuous girl.

When adequate descriptions were obtained of contacts in other parts of the country I sent them to Medical Officers of Health concerned.

It was impossible to gain enough information from some patients, including those who were in a hurry to return to work after treatment, some who remembered nothing, some who had been infected abroad, and many who spoke very little English. I understand that now we can have help from the Ministry of Health in tracing contacts living abroad.

Quite a number of patients were not subjected to this routine questioning, either because I was not on duty at the time, or because I was visiting contacts. I found it difficult to know when to be in the clinic and when to visit. After a fruitless visiting session it was frustrating to return to the clinic to find that several infected men had been treated in the meantime and had left. It was always possible they might not return although they had been asked to do so. Visits made during the hours of duty were most time-consuming.

The tracing of contacts presented many difficulties. In some cases I was given false addresses. Sometimes contacts had only just moved away or had been turned out by irate landladies. On several occasions the woman concerned had been admitted to hospital with severe pains in the stomach, presumably due to salpingitis. I often had to make many visits before finding a contact at home and even when at last she was traced, the interview was not easy. It was essential to speak to the woman alone because of the confidential nature of the subject. I had to be very careful not to mention venereal disease and not to mention any names, though at times I wondered if I was being too cautious. I once telephoned a middleaged prostitute but failed to persuade her to attend. Later, however, I managed to find her address. I 
then visited her and, in the middle of our conversation, in walked one of her male friends. She welcomed him with the words "Here's the lady who telephoned me the other day; she wants me to go to the hospital to see if I have got V.D." When I did manage to get her on one side, to say that the matter was very confidential, she answered "Sid's O.K.: he knows all about V.D. and has told me it can make me barmy". She returned with me to hospital and was found to be infected with gonorrhoea!

Many contacts asked the inevitable question of "who gave my name?" Some said that they were "clean"; some disliked hospitals, doctors, and particularly "needles". There were those who understandably resented the suggestion from a complete stranger that they should attend the clinic for tests.

My visits were very, very varied and so too were the contacts. There were charming West End hostesses, students, young factory girls, many West Indians, and chatty middle-aged women, widowed or separated from their husbands. The latter group often addressed me cosily with "You're a woman of the world; you know what it is", and proceeded to tell me the history of their affairs. There were also girls who said that they intended to sue me and those who asserted that they were virgins.

Nevertheless, some were really grateful and attended willingly and regularly. I managed to maintain a good relationship with patients with this outlook.

I found that having a car saved a great deal of time when visiting. The most successful procedure was to ask contacts to return to hospital at once in the car; promises to come later often proved unreliable. Parking difficulties of course were a hazard. Sometimes I set off with a patient who had offered to take me to the contact in a café or club. He would expect me to leave the car outside whatever the parking restrictions whilst arguments continued with the girl, he accusing her of infecting him and she protesting her innocence. One prostitute whom I telephoned, offered to attend if I could fetch her, as she did not feel well enough to undergo the rigours of London Transport. I agreed to collect her and found I was unable to park outside her home. I advised her to come out quickly. She did. I found her sitting beside me in a flimsy nightdress and bedroom slippers with a coat thrown round her shoulders. I was anxious to depart but the car would not start. She was full of solicitude and offered to go and fetch a mechanic from a nearby garage. I thanked her but refused her help as I felt sure we would get away in a few moments. We did so too, but not before one of her clients arrived, whereon she jumped out of the car to postpone his visit to a more appropriate time.

Another time I was bringing a girl to Whitechapel and she seemed to become more and more disturbed as we neared the hospital. Indeed I wondered if she was going to attack me. She was known to me as a drug addict. However, it appeared that her husband had knifed a male friend of hers and that the victim of his fury was an in-patient in The London Hospital and was near to death. The Police were still searching for the attacker and she was terrified that her husband would knife her too if he knew where she had been. I suggested we should go to another clinic but she decided to come to Whitechapel and to give a false name and address. The results of her tests were positive for gonorrhoea.

If a contact preferred to attend a clinic nearer her home she was encouraged to do so; the times of that clinic were given to her and I notified the Welfare Officer concerned.

I had to make many calls in the evening because the women were at work during the day, and I found it a great disadvantage in such cases not to be able to return with them straightaway to the clinic. I was unhappy to meet fathers and mothers of young girls, as I always felt they were very suspicious whatever I said and when I casually mentioned that I happened to be passing and had a message from a friend they naturally asked me to give them the message.

Prostitutes were difficult to trace because they used so many different names and could change their appearance quickly and easily. Their addresses changed as quickly as their names and coiffures. They would also change their professional area for a few weeks and then return again. The whole situation was not conducive to detection.

My particular problem at the Whitechapel Clinic during 1965 was the large attendance of male patients with early infectious syphilis. The majority of these men were Pakistanis who were living in the sordid Brick Lane area near the hospital. These immigrants are not, so far as I know, particularly promiscuous, but they are not easily assimilated into ordinary English society, partly because they speak very little English and partly because of their different customs; thus they cannot easily find ordinary girl friends and resort to local prostitutes. To get descriptions of contacts from such patients was well-nigh impossible. Apart from the language difficulty they were extremely reticent and loth to discuss their personal affairs. Often the infection had been acquired some weeks earlier and this made it impossible for the patient to give me adequate information, even with the aid of an interpreter. 
However, a pattern of what was taking place soon became evident. I gathered that the prostitutes called at the houses where the Pakistanis lodged. A girl would go into the room of one man, who would not have to pay, and then the other men in the house could come to her, have intercourse, leave money, and depart. The room was probably dark and the men would hardly see her. The prostitutes found this very easy and very lucrative, since soliciting as such was unnecessary and, should anyone recognize the girl, his limited command of English would debar him from describing her, even if he wished to do so, which was unlikely.

I arranged a meeting with a Pakistani Welfare Officer, whose office was just off Brick Lane. I asked him to emphasize to his fellow-countrymen the danger of contracting syphilis from the local prostitutes and to persuade them to attend Whitechapel Clinic if they suspected that they had acquired an infection. He seemed very eager to help and promised to discuss the matter with his committee and to let me know of any suggestions they might make for preventing the continuance of the epidemic. He did emphasize, however, that he too was handicapped in discussing the problems with his countrymen as he knew they would feel shy and above all guilty because of their strict religious laws.

I also discussed the matter with the Medical Officer of Health. He suggested that someone should accompany me on my visits to the most sordid cafés and clubs, but I decided that this might associate me with officialdom, a situation I hoped to avoid.

Because it seemed impossible to get descriptions of contacts from this group of immigrants I decided to try to bring into the clinic the prostitutes who could be seen around the area, in the cafés and clubs mostly patronized by Pakistanis. I felt that if I could gain the confidence of these girls I might be able to persuade them to attend the clinic regularly for tests. I explained to them the dangers of the infection to which they might be exposed and its damaging results if left untreated. One or two prostitutes attended and promised to warn their friends. One of these who did attend as a result of my warning, confirmed what we had already supposed.

She was a fairly well educated girl who had left school and married because she was pregnant. Because she was unhappy with her husband she left him and came to London, where she was directed to the Salvation Army Hostel near Brick Lane. She was an attractive girl and a Maltese ponce quickly saw her possibilities as a financial investment. She moved in with him and is very fond of him. Her clients now are practically all Pakistani immigrants. She told me she could find twenty or more in a house and thus earn a quick income with no questions asked. She actually mentioned $£ 20$ a half hour but I felt this was rather an exaggeration, the usual rate being $f 1$ per client. On her own admission she could have infected hundreds of Pakistanis. Although she was suffering from early syphilis I was not able to include her as a "syphilis contact brought under treatment" because I was unable to get a description of her from any patient; but she most certainly was one.

From the time that I began this work in midDecember, 1964, to October, 1965, the number of male Pakistanis infected with early syphilis treated at Whitechapel Clinic was 61 compared with 47 of all other nationalities, including five Indians (Figure, opposite).

There were only two by February, 1965, but in March the figure increased to eighteen. The number then dropped until July, 1965, when there were eleven. Again there was a drop until September, 1965, when there were sixteen and then another fall. During this time eight prostitutes from the area concerned were treated at the clinic for infectious syphilis. These girls were probably the cause of much of the epidemic. The first was not known to me but the others were and may or may not have attended because of my efforts. They might have attended anyway eventually because of disquieting symptoms but from past experience this does not seem likely. In the meantime they might have infected hundreds of men and converted this minor outbreak into a major epidemic.

I received a notification from Copenhagen of a prostitute said to have infected a Dane with primary syphilis. I called on this woman and she was brought to the clinic and treated for infectious syphilis.

On the whole I found contact tracing interesting and worthwhile, but it was difficult and often dispiriting in its fluctuating success. Many places visited were sordid and dirty, but I had a feeling of satisfaction when an infected woman was brought for treatment. I did wonder if patients would prefer to attend at other clinics in order to avoid being bothered about contact tracing, though I found most of them seemed to appreciate the importance of the procedure when it was explained to them. I was also anxious to avoid pushing the prostitutes around too much because this would be likely to have the effect of alienating them and perhaps dispersing them to another district when the aim of routine attendance would be thwarted. I considered very seriously the possible advantages of an unofficial liaison with the Police who, after all, know the 


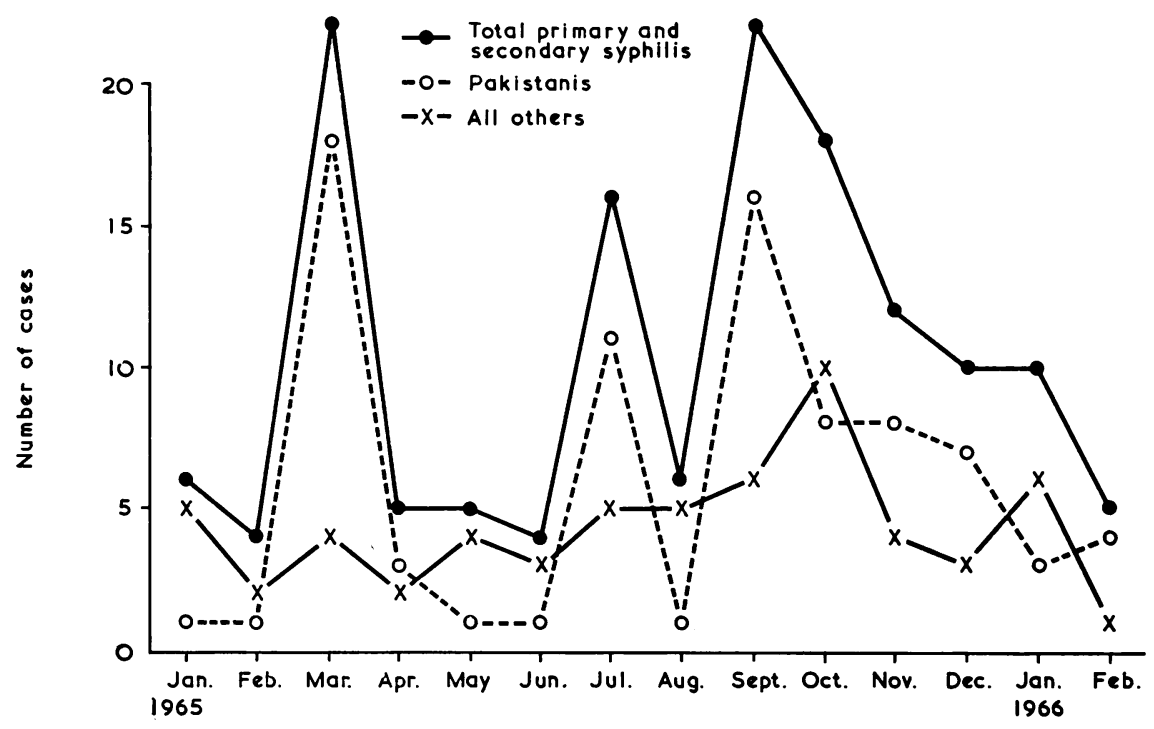

area well and have lists of names and addresses of prostitutes and professional ways of tracing people.

I am sure that it is possible to be more successful in this work. At first I was new to the neighbourhood. It took some time to get to know the area and other workers engaged in the social services. More success is to be anticipated from getting to know and obtaining the confidence of local prostitutes and other promiscuous women. By this means more of them can probably be induced to attend regularly for precautionary examination and tests. One must bear in mind also that the Whitechapel Clinic is open for the reception of new patients for 50 hours a week and that my hours of duty are $36 \frac{3}{4}$. If I spent half that time visiting I should be in the clinic for only 18 or 19 hours a week. In fact this is full-time work for at least two people. One must also consider the disproportionate time spent in dealing with those who speak little or no English. To save this time more and better interpreters are required.

The Table indicates the degree of success obtained in contact tracing in the first 10 months of 1965 as compared with the corresponding period of 1964 . At The London Hospital from January to October, 1964 , of the primary contacts of 59 male patients suffering from early syphilis, only one came to be examined and she was not found to be infected. During the same period in 1965 , when active contact tracing was pursued, out of 107 primary contacts, thirteen $(12.1$ per cent.) were examined and ten (77 per cent.) were found to be infected. Similarly, from January to October, 1964, out of 1,355 primary contacts of male cases of gonorrhoea, $143(10.6$
TABLE

RESULTS OF CONTACT TRACING

\begin{tabular}{|c|c|c|c|c|c|c|}
\hline \multirow{3}{*}{ Infection } & \multirow{3}{*}{$\begin{array}{l}\text { Period of } \\
\text { Study }\end{array}$} & \multirow{3}{*}{$\begin{array}{c}\text { Total } \\
\text { Male } \\
\text { Patients }\end{array}$} & \multicolumn{4}{|c|}{ Contacts } \\
\hline & & & \multicolumn{2}{|c|}{ Attended } & \multicolumn{2}{|c|}{$\begin{array}{l}\text { Found to be } \\
\text { Infected }\end{array}$} \\
\hline & & & No. & $\begin{array}{c}\text { Per } \\
\text { cent.* }\end{array}$ & No. & $\begin{array}{l}\text { Per } \\
\text { cent. } \dagger\end{array}$ \\
\hline Syphilis & $\begin{array}{l}\text { Jan.-Oct., } 1964 \\
\text { Jan.-Oct., } 1965\end{array}$ & $\begin{array}{r}59 \\
107\end{array}$ & $\begin{array}{r}1 \\
13\end{array}$ & $\begin{array}{r}1 \cdot 7 \\
12 \cdot 1\end{array}$ & $\begin{array}{r}0 \\
10\end{array}$ & $\overline{77 \cdot 0}$ \\
\hline Gonorrhoea & $\begin{array}{l}\text { Jan.-Oct., } 1964 \\
\text { Jan.-Oct., } 1965\end{array}$ & $\begin{array}{l}1,355 \\
1,021\end{array}$ & $\begin{array}{l}143 \\
201\end{array}$ & $\begin{array}{l}10 \cdot 6 \\
19 \cdot 7\end{array}$ & $\begin{array}{l}121 \\
166\end{array}$ & $\begin{array}{l}84 \cdot 5 \\
82 \cdot 5\end{array}$ \\
\hline
\end{tabular}

* Percentage of female contacts of male patients.

$\dagger$ Percentage of number of women who attended.

per cent.) attended and 121 ( 84.5 per cent.) were found to be infected. During the same period in 1965, when contact tracing was being actively pursued, out of 1,021 primary contacts $201(19 \cdot 7$ per cent.) attended, and $166(82.5$ per cent.) of them were found to be infected.

I am grateful for the help I had from Miss B. Muspratt at Whitechapel Clinic and from workers at other clinics; from Holloway Prison, and from Probation Officers. The Medical Officer of Health of The Borough of Tower Hamlets has shown interest and sympathy and the Health Education Officer has paid me several visits and offered aid should it be needed. The staff at Whitechapel Clinic were kind, considerate, and helpful, and I was welcomed into a very friendly atmosphere. I have now been provided with a newly constructed room and a private telephone, all of which I am sure will be of tremendous assistance in my aim to lessen the spread of venereal disease by contact tracing. 